\title{
EFEKTIVITAS PENERAPAN METODE JARIMATIKA DALAM PEMBELAJARAN MATERI PERKALIAN DI KELAS 2 MI AL-MUSTOFA SURABAYA
}

\author{
Nurul Wachidah ${ }^{1}$, Iis Holisin ${ }^{2}$, Wudjud SD ${ }^{3}$ \\ Program Studi Pendidikan Matematika, FKIP UMSurabaya \\ nurulwachidah2011@gmail.com
}

\begin{abstract}
ABSTRAK
Permasalahan dalam penelitian ini adalah nilai hasil belajar matematika siswa yang masih kurang dan belum mencapai kriteria ketuntasan minimal. Subyek dalam penelitian ini adalah siswa kelas 2 MI Al-Mustofa Surabaya yang berjumlah 18 siswa, terdiri dari 10 siswa laki-laki dan 8 siswa perempuan. Metode dalam penelitian ini adalah metode deskriptif kuantitatif. Adapun instrumen dalam penelitian ini adalah tes tulis bentuk multiple choise dan uraian, lembar observasi aktivitas siswa dan guru, lembar observasi kemampuan guru dalam mengelola pembelajaran, lembar angket respon siswa. Hasil Penelitian ini menunjukkan siswa yang tuntas belajar sebanyak 75\%. Aktivitas siswa dan guru berada dalam waktu ideal yang sudah ditentukan sebelumnya. Kemampuan guru dalam mengelola pembelajaran menunjukkan tingkat kemampuan guru yang baik. Respon siswa terhadap penerapan metode jarimatika menunjukkan respon positif. Oleh karena itu, metode jarimatika efektif digunakan dalam pembelajaran materi perkalian kelas 2 siswa MI Al-Mustofa Surabaya.
\end{abstract}

Kata kunci: efektivitas pembelajaran; metode jarimatika.

\section{PENDAHULUAN}

Matematika merupakan salah satu mata pelajaran pokok yang harus dikuasai anak dan kebanyakan anak menganggap sulit. Guru yang mengajarkan matematika di SD selalu bertanya-tanya tentang apa yang perlu diciptakan supaya murid belajar lebih efektif dan menyenangkan. Menganalisis proses pembelajaran pada intinya tertumpu pada suatu persoalan, yaitu bagaimana guru memberi kemungkinan bagi siswa agar terjadi proses belajar yang efektif serta dapat mencapai hasil sesuai tujuan.

Untuk menciptakan suasana yang menyenangkan dan tidak menakutkan, guru perlu menggunakan sebuah metode dalam mengajar. Hasil wawancara peneliti kepada guru kelas 2 pada hari jum'at tanggal 13 Maret 2015 di sekolah MI Al Mustofa, diperoleh informasi bahwa pada proses pembelajaran matematika banyak ditemui permasalahan. Salah satu masalah yang sering dihadapi guru adalah siswa tidak hafal dalam mengoperasikan perkalian, terutama perkalian 6 s/d 10. Sehingga siswa kesulitan menyelesaikan soal perkalian. 
Siswa kelas 2 yang kurang mampu mengoperasikan perkalian, membuat siswa kesulitan dalam menyelesaikan soal-soal matematika yang diberikan guru selanjutnya. Sebagai bukti setelah melakukan observasi berdasarkan nilai standar kriteria ketuntasan minimal (KKM) matematika kelas 2 yaitu 60, ada 70\% dari 18 siswa kelas 2 mendapatkan nilai $\leq 60$.

Berdasarkan uraian di atas, peneliti memandang perlu melakukan penanggulangan dengan melaksanakan penelitian. Penelitian ini membahas tentang efektivitas penerapan metode jarimatika dalam pembelajaran materi perkalian di kelas 2 MI Al-Mustofa Surabaya.

\section{METODE PENELITIAN}

Peneliti menggunakan penelitian deskriptif kuantitatif untuk mendiskripsikan tentang efektifitas penerapan metode jarimatika dalam pembelajaran materi perkalian. Sedangkan data kuantitatif digunakan untuk menganalisis data yang meliputi data ketuntaan belajar siswa, data kemampuan guru dalam mengelola pembelajaran, aktivitas siswa dan guru, angket respon siswa.

Subjek dalam penelitian ini adalah siswa kelas 2 MI Al-Mustofa Surabaya sebanyak 18 siswa dengan ciri-ciri sebagai berikut:

1. Siswa berjenis kelamin laki-laki sebanyak 10 anak dan berjenis kelamin perempuan sebanyak 8 anak.

2. 6 siswa memiliki kemampuan membaca, menulis dan berhitung dengan baik.

3. 10 siswa memiliki kemampuan membaca, menulis dan berhitung dengan cukup baik dan 2 siswa memiliki kemampuan yang kurang baik.

Keberhasilan penelitian banyak ditentukan oleh instrumen yang digunakan, sebab data yang diperlukan untuk pertanyaan dalam penelitian ini diperoleh melalui instrumen yang diberikan kepada siswa. Dan teknik pengumpulan data merupakan sebuah teknik yang digunakan oleh seorang peneliti dalam memperoleh data yang dibutuhkan.

Adapun teknik pengumpulan data dalam penelitian ini adalah teknik tes, teknik observasi, dan teknik angket. Data yang digunakan dalam penelitian ini adalah data kuantitatif yang selanjutnya akan dianalisis seacara deskriptif dengan 
tujuan untuk menyajikan data hasil pengamatan secara jelas. Data yang dianalisis secara deskriptif dalam penelitian ini adalah data ketuntasan belajar siswa, respon siswa selama proses pembelajaran, aktivitas siswa dan guru selama proses pembelajaran, dan kemampuan guru dalam mengelola pembelajaran.

\section{HASIL PENELITIAN DAN PEMBAHASAN}

\section{Hasil Penelitian}

Proses penelitian ini diawali dengan melakukan uji homogenitas dua sekolahan yaitu MI Al-Mustofah dan MI Al-Muthmainnah untuk melihat kesamaan varians. Kemudian dilanjutkan dengan uji validitas dan reliabilitas tes hasil belajar di MI Al-Muthmainnah dengan jumlah siswa 23 dan penelitian dilakukan di MI Al-Mustofah dengan jumlah siswa 18. MI Al-Muthmainnah dipilih sebagai sekolah uji validitas dan reliabilitas tes karena lokasi sekolah tidak jauh dari sekolah MI Al-Mustofa dan 1 kelurahan dengan sekolahan MI AlMustofa serta kelas yang dipilih memiliki kesamaan (homogen). Proses pengambilan data pada penelitian ini dimulai tanggal 15 April 2015 dan berakhir pada tanggal 30 April 2015.

Sesuai dengan metode pengumpulan data yang sudah direncanakan, maka hasil penelitian ini dapat dikelompokkan menjadi tiga, yaitu : data tes hasil belajar, data hasil observasi, dan data hasil angket.

Tes ketuntasan belajar siswa diikuti oleh 16 siswa dan 2 siswa tidak hadir karena 1 siswa pulang ke desa dan 1 siswa yang lain sakit. Data tes ketuntasan belajar siswa pada mata pelajaran matematika dengan penerapan metode jarimatika, diperoleh sebagai berikut:

Tabel 1: Skor Tes Ketuntasan Belajar Siswa

\begin{tabular}{|c|l|c|c|c|}
\hline No & \multicolumn{1}{|c|}{ Nama Siswa } & KKM & Skor & Keterangan \\
\hline 1 & Anisatul M & 60 & 74 & Tuntas \\
\hline 2 & Erwin Aditya S & 60 & 46 & Belum Tuntas \\
\hline 3 & Faizah & 60 & 50 & Belum Tuntas \\
\hline 4 & Galang Jon W & 60 & 68 & Tuntas \\
\hline 5 & Idrus Afandi & 60 & 42 & Belum Tuntas \\
\hline 6 & Kartika Cinta & 60 & 72 & Tuntas \\
\hline 7 & Linda Lestari & 60 & 66 & Tuntas \\
\hline
\end{tabular}


Efektivitas Penerapan Metode Jarimatika Dalam Pembelajaran Materi Perkalian

\begin{tabular}{|c|l|c|c|c|}
\hline No & \multicolumn{1}{|c|}{ Nama Siswa } & KKM & Skor & Keterangan \\
\hline 8 & M. Abi Dzar & 60 & 86 & Tuntas \\
\hline 9 & M. Baladar Rosul & 60 & 68 & Tuntas \\
\hline 10 & M. Baharudin Tamam & 60 & 72 & Tuntas \\
\hline 11 & M. Firdaus A & 60 & 66 & Tuntas \\
\hline 12 & M. Habib Rojak A & 60 & 79 & Tuntas \\
\hline 13 & Nadhifa Ayu W & 60 & 79 & Tuntas \\
\hline 14 & Rina Hendaryanti & 60 & - & Tuntas \\
\hline 15 & Saskia M. Azzahroh & 60 & 83 & - \\
\hline 16 & Satris & 60 & - & Belum Tuntas \\
\hline 17 & Sulaiman & 60 & 46 & Tuntas \\
\hline 18 & Ziadaturrohmatun N & 60 & 72 & \\
\hline
\end{tabular}

Data di atas adalah hasil tes penelitian yang dilaksanakan setelah siswa menerima penerapan metode jarimatika. Dari hasil perhitungan di atas diperoleh:

Tuntas

$$
=12 \text { Siswa }
$$

Belum Tuntas

$$
=4 \text { Siswa }
$$

Ketuntasan secara klasikal dapat dilihat sebagai berikut:

$$
\begin{aligned}
\mathrm{T}_{\mathrm{K}} & =\frac{\sum \mathrm{S}_{\mathrm{B}}}{\sum \mathrm{S}_{\mathrm{R}}} \times 100 \% \\
& =\frac{12}{16} \times 100 \% \\
& =75 \%
\end{aligned}
$$

Berdasarkan data ketuntasan belajar di atas, diperoleh secara klasikal ada $75 \%$ siswa yang tuntas.

Data kemampuan guru diperoleh dari lembar observasi kemampuan guru dalam mengelola pembelajaran. Data kemampuan guru secara terperinci dapat dilihat pada lampiran, sedangkan analisis data kemampuan guru dalam mengelola pembelajaran dapat dilihat pada tabel berikut:

Tabel 2: Data Kemampuan Guru dalam Mengelola Pembelajaran

\begin{tabular}{|c|l|c|c|c|c|c|}
\hline \multirow{2}{*}{ No } & \multicolumn{1}{|c|}{ Aspek yang dinilai } & \multicolumn{4}{|c|}{ Pertemuan } \\
\cline { 3 - 6 } $\mathbf{1}$ & $\begin{array}{l}\text { Persiapan } \\
\text { a. Materi yang dikuasai }\end{array}$ & 4 & 4 & 4 & 4 & 4 \\
\cline { 2 - 6 } & \multicolumn{1}{|c|}{ Rata-rata Tiap Aspek } & 4.0 & 4.0 & 4.0 & 4.0 & 4.0 \\
\hline \multirow{2}{*}{$\begin{array}{l}\text { Pendahuluan } \\
\text { a. Membuka pelajaran dan mempersiapkan } \\
\begin{array}{l}\text { siswa untuk belajar } \\
\text { b. Memotivasi siswa } \\
\text { c. Menyampaikan indikator pembelajaran } \\
\text { d. Menyampaikan tujuan pembelajaran }\end{array}\end{array}$} & 14 & 15 & 14 & 15 & 15 \\
\hline
\end{tabular}


Nurul Wachidah', Iis Holisin ${ }^{2}$, Wudjud $S D^{3}$

\begin{tabular}{|c|c|c|c|c|c|c|}
\hline \multirow{4}{*}{ No } & \multirow{2}{*}{ Aspek yang dinilai } & \multicolumn{5}{|c|}{ Pertemuan } \\
\hline & & \multirow{2}{*}{1} & \multirow[t]{2}{*}{2} & \multirow[t]{2}{*}{3} & \multirow[t]{2}{*}{4} & \multirow{2}{*}{5} \\
\hline & $\begin{array}{l}\text { e. Menghubungkan pembelajaran hari ini } \\
\text { dengan pembelajaran sebelumnya }\end{array}$ & & & & & \\
\hline & Rata-rata Tiap Aspek & 2.8 & 3.0 & 2.8 & 3.0 & 3.0 \\
\hline \multirow[t]{2}{*}{3} & $\begin{array}{l}\text { Kegiatan Inti } \\
\text { a. Memberikan masalah kontekstual (LKS) } \\
\text { b. Mengarahkan siswa untuk membaca dan } \\
\text { memahami masalah } \\
\text { c. Mengamati aktivitas siswa dalam } \\
\text { menyelesaikan masalah } \\
\text { d. Memberikan bantuan dan petunjuk- } \\
\text { eetunjuk seperlunya } \\
\text { e. Memberikan penghargaan } \\
\text { f. Mengoptimalkan interaksi siswa } \\
\text { g. Mendorong siswa untuk menuangkan } \\
\text { ide/pendapat pada saat diskusi } \\
\text { h. Menghargai berbagai pendapat siswa } \\
\text { i. Mengarahkan siswa untuk } \\
\text { bertanya/menjawab pertanyaan dari } \\
\text { guru/teman }\end{array}$ & 25 & 26 & 27 & 27 & 27 \\
\hline & Rata-rata Tiap Aspek & 2.8 & 2.9 & 3.0 & 3.0 & 3.0 \\
\hline \multirow[t]{2}{*}{4} & $\begin{array}{l}\text { Penutup } \\
\text { a. Menegaskan kembali kesimpulan materi } \\
\text { b. Memberi tugas rumah } \\
\text { c. Menutup pelajaran }\end{array}$ & 9 & 8 & 9 & 8 & 8 \\
\hline & Rata-rata Tiap Aspek & 3.0 & 2.7 & 3.0 & 2.7 & 2.7 \\
\hline \multirow{2}{*}{5} & Pengelolaan Waktu & 3.0 & 3.0 & 3.0 & 3.0 & 3.0 \\
\hline & Rata-rata Tiap Aspek & 3.0 & 3.0 & 3.0 & 3.0 & 3.0 \\
\hline \multirow[t]{4}{*}{6} & $\begin{array}{l}\text { Suasana Kelas } \\
\text { a. Berpusat pada siswa } \\
\text { b. Antusias guru } \\
\text { c. Antusias siswa }\end{array}$ & 9 & 9 & 9 & 12 & 12 \\
\hline & Rata-rata Tiap Aspek & 3.0 & 3.0 & 3.0 & 4.0 & 4.0 \\
\hline & Tingkat Kemampuan Guru & 3.10 & 3.09 & 3.13 & 3.28 & 3.28 \\
\hline & Kategori Penilaian & Baik & Baik & $\begin{array}{c}\text { Bai } \\
\mathbf{k}\end{array}$ & Baik & Baik \\
\hline
\end{tabular}

Aktivitas siswa selama berlangsungnya pembelajaran matematika dengan penerapan metode jarimatika pada materi perkalian, disajikan pada tabel berikut: 
Tabel 3: Data Hasil Pengamatan Aktivitas Siswa dengan Penerapan Metode Jarimatika

\begin{tabular}{|c|c|c|c|c|c|c|c|c|c|c|}
\hline No & Jenis Kegiatan & $\mathbf{P 1}$ & $\mathbf{P 2}$ & P3 & P4 & P5 & $\begin{array}{l}\text { Rata- } \\
\text { rata }\end{array}$ & $\begin{array}{c}\text { Waktu } \\
\text { yang } \\
\text { digunakan } \\
(\%)\end{array}$ & $\begin{array}{c}\text { Rentang } \\
\text { waktu } \\
\text { ideal } \\
\text { dengan } \\
\text { toleransi } 5 \\
\text { menit } \\
(\%)\end{array}$ & Keterangan \\
\hline 1 & $\begin{array}{l}\text { Memperhatikan } \\
\text { penjelasan } \\
\text { guru/teman } \\
\text { (pendahuluan/pe } \\
\text { nutup, motivasi, } \\
\text { bahan } \\
\text { pengait/apersepsi } \\
\text {, tujuan } \\
\text { pembelajaran, } \\
\text { materi pelajaran, } \\
\text { contoh materi, } \\
\text { penggunaan } \\
\text { metode } \\
\text { jarimatika) }\end{array}$ & 117 & 110 & 55 & 84 & 100 & 93.2 & 29.13 & $29 \leq x \leq 39$ & Efektif \\
\hline 2 & $\begin{array}{l}\text { Aktif dalam } \\
\text { kegiatan (diskusi } \\
\text { kelompok, game, } \\
\text { pelajaran) }\end{array}$ & 16 & 10 & 16 & 44 & 16 & 20.4 & 6.38 & $6 \leq x \leq 16$ & Efektif \\
\hline 3 & $\begin{array}{l}\text { Tanya jawab } \\
\text { kepada } \\
\text { guru/teman } \\
\text { (mengemukakan } \\
\text { pendapat, } \\
\text { presentasi di } \\
\text { depan kelas, } \\
\text { mendengarkan } \\
\text { percakapan } \\
\text { diskusi) }\end{array}$ & 28 & 26 & 38 & 12 & 21 & 25 & 7.81 & $6 \leq x \leq 16$ & Efektif \\
\hline 4 & $\begin{array}{l}\text { Membaca } \\
\text { masalah / materi } \\
\text { pelajaran }\end{array}$ & 24 & 23 & 17 & 0 & 0 & 12.8 & 4.00 & $2 \leq x \leq 12$ & Efektif \\
\hline 5 & $\begin{array}{l}\text { Mengerjakan / } \\
\text { menyelesaikan } \\
\text { masalah (latihan } \\
\text { soal, tes, game, } \\
\text { LKS) }\end{array}$ & 22 & 38 & 32 & 37 & 64 & 38.6 & 12.06 & $12 \leq x \leq 22$ & Efektif \\
\hline 6 & $\begin{array}{l}\text { Melakukan / } \\
\text { mempraktekkan } \\
\text { metode } \\
\text { jarimatika }\end{array}$ & 0 & 0 & 48 & 34 & 16 & 19.6 & 6.13 & $6 \leq x \leq 16$ & Efektif \\
\hline 7 & $\begin{array}{l}\text { Membuat / } \\
\text { menarik } \\
\text { kesimpulan } \\
\text { (prosedur/konsep } \\
\text {, tekhnik/cara, }\end{array}$ & 16 & 16 & 16 & 12 & 6 & 13.2 & 4.13 & $2 \leq x \leq 12$ & Efektif \\
\hline
\end{tabular}




\begin{tabular}{|c|c|c|c|c|c|c|c|c|c|c|}
\hline No & Jenis Kegiatan & P1 & P2 & P3 & P4 & P5 & $\begin{array}{l}\text { Rata- } \\
\text { rata }\end{array}$ & $\begin{array}{c}\text { Waktu } \\
\text { yang } \\
\text { digunakan } \\
(\%)\end{array}$ & $\begin{array}{c}\text { Rentang } \\
\text { waktu } \\
\text { ideal } \\
\text { dengan } \\
\text { toleransi } 5 \\
\text { menit } \\
(\%) \\
\end{array}$ & Keterangan \\
\hline & $\begin{array}{l}\text { pengertian } \\
\text { sebuah materi) }\end{array}$ & & & & & & & & & \\
\hline 8 & $\begin{array}{l}\text { Perilaku yang } \\
\text { tidak relevan } \\
\text { (berbicara } \\
\text { sendiri, } \\
\text { bercanda, dll) }\end{array}$ & 1 & 1 & 2 & 1 & 1 & 1.2 & 0.38 & $0 \leq x \leq 5$ & Efektif \\
\hline
\end{tabular}

Aktivitas Guru selama proses pembelajaran berlangsung dengan penerapan metode jarimatika pada materi perkalian, disajikan pada tabel berikut:

Tabel 4: Data Hasil Pengamatan Aktivitas Guru dengan Penerapan Metode Jarimatika

\begin{tabular}{|c|c|c|c|c|c|c|c|c|c|c|}
\hline \multirow[b]{2}{*}{ No } & \multirow[b]{2}{*}{$\begin{array}{c}\text { Jenis } \\
\text { Kegiatan }\end{array}$} & \multicolumn{5}{|c|}{ RPP } & \multirow[b]{2}{*}{$\begin{array}{c}\text { Rata- } \\
\text { rata }\end{array}$} & \multirow[b]{2}{*}{$\begin{array}{c}\text { Waktu } \\
\text { yang } \\
\text { digunakan } \\
(\%)\end{array}$} & \multirow{2}{*}{$\begin{array}{c}\text { Rentang } \\
\text { waktu } \\
\text { ideal } \\
\text { dengan } \\
\text { toleransi } 5 \\
\text { menit } \\
(\%)\end{array}$} & \multirow[b]{2}{*}{ Katerangan } \\
\hline & & P1 & $\mathbf{P 2}$ & P3 & P4 & P5 & & & & \\
\hline 1 & $\begin{array}{l}\text { Menyampaika } \\
\text { n pendahuluan } \\
\text { (salam, } \\
\text { menyiapkan } \\
\text { siswa belajar) }\end{array}$ & 1 & 1 & 1 & 1 & 1 & 1.00 & 5 & $2 \leq x \leq 12$ & Efektif \\
\hline 2 & $\begin{array}{l}\text { Menyampaika } \\
\mathrm{n} \text { bahan } \\
\text { (pengait/aperse } \\
\text { psi, tujuan } \\
\text { pembelajaran, } \\
\text { materi } \\
\text { pelajaran) }\end{array}$ & 2 & 1 & 3 & 2 & 1 & 1.80 & 9 & $9 \leq x \leq 19$ & Efektif \\
\hline 3 & $\begin{array}{l}\text { Memotivasi } \\
\text { siswa untuk } \\
\text { melibatkan diri } \\
\text { dan semangat } \\
\text { dalam } \\
\text { mengikuti } \\
\text { kegiatan } \\
\text { pembelajaran }\end{array}$ & 3 & 2 & 1 & 1 & 1 & 1.60 & 8 & $2 \leq x \leq 12$ & Efektif \\
\hline 4 & $\begin{array}{l}\text { Memberi } \\
\text { contoh } \\
\text { (kehidupan } \\
\text { sehari-hari } \\
\text { atau } \\
\text { kontekstual) }\end{array}$ & 1 & 1 & 1 & 1 & 0 & 0.80 & 4 & $2 \leq x \leq 12$ & Efektif \\
\hline
\end{tabular}




\begin{tabular}{|c|c|c|c|c|c|c|c|c|c|c|}
\hline \multirow[b]{2}{*}{ No } & \multirow[b]{2}{*}{$\begin{array}{c}\text { Jenis } \\
\text { Kegiatan }\end{array}$} & \multicolumn{5}{|c|}{ RPP } & \multirow[b]{2}{*}{$\begin{array}{l}\text { Rata- } \\
\text { rata }\end{array}$} & \multirow{2}{*}{$\begin{array}{c}\text { Waktu } \\
\text { yang } \\
\text { digunakan } \\
(\%)\end{array}$} & \multirow{2}{*}{$\begin{array}{c}\text { Rentang } \\
\text { waktu } \\
\text { ideal } \\
\text { dengan } \\
\text { toleransi } 5 \\
\text { menit } \\
(\%)\end{array}$} & \multirow[b]{2}{*}{ Katerangan } \\
\hline & & P1 & P2 & P3 & P4 & P5 & & & & \\
\hline 5 & $\begin{array}{l}\text { Memberikan } \\
\text { kesempatan } \\
\text { kepada siswa } \\
\text { untuk terlibat } \\
\text { aktif dalam } \\
\text { kegiatan } \\
\text { pembelajaran } \\
\text { (tanya jawab, } \\
\text { mengemukaka } \\
\text { n pendapat) }\end{array}$ & 2 & 3 & 1 & 1 & 1 & 1.60 & 8 & $4 \leq x \leq 14$ & Efektif \\
\hline 6 & $\begin{array}{l}\text { Menggunakan } \\
\text { / } \\
\text { mempraktekka } \\
\text { n (alat/media } \\
\text { pelajaran, } \\
\text { metode } \\
\text { jarimatika, } \\
\text { sumber } \\
\text { belajar) }\end{array}$ & 0 & 0 & 2 & 3 & 0 & 1.00 & 5 & $5 \leq x \leq 15$ & Efektif \\
\hline 7 & $\begin{array}{l}\text { Memberikan } \\
\text { latihan (tes, } \\
\text { game) }\end{array}$ & 2 & 2 & 3 & 3 & 7 & 3.40 & 17 & $16 \leq x \leq 26$ & Efektif \\
\hline 8 & $\begin{array}{l}\text { Mengamati } \\
\text { kegiatan siswa } \\
\text { (mengerjakan } \\
\text { latihan, } \\
\text { membentuk } \\
\text { kelompok, } \\
\text { diskusi) }\end{array}$ & 2 & 3 & 1 & 1 & 2 & 1.80 & 9 & $9 \leq x \leq 19$ & Efektif \\
\hline 9 & $\begin{array}{l}\text { Menyimpulkan } \\
\text { dan menutup } \\
\text { pelajaran }\end{array}$ & 1 & 1 & 1 & 1 & 1 & 1.00 & 5 & $5 \leq x \leq 15$ & Efektif \\
\hline 10 & $\begin{array}{l}\text { Perilaku yang } \\
\text { tidak relevan }\end{array}$ & 0 & 0 & 0 & 0 & 0 & 0.00 & 0 & $0 \leq x \leq 5$ & Efektif \\
\hline
\end{tabular}

Data respon siswa terhadap penerapan metode jarimatika diperoleh dari angket. Perhitungan data respon siswa dapat dilihat secara terperinci dapat dilihat pada lampiran, sedangkan analisis data respon siswa terhadap kegiatan pembelajaran dapat dilihat pada tabel di bawah ini: 
Tabel 5: Respon Siswa terhadap Penerapan Metode Jarimatika

\begin{tabular}{|c|c|c|c|c|}
\hline \multirow{2}{*}{ No } & \multirow{2}{*}{ Pernyataan } & \multicolumn{2}{|c|}{ Respon Siswa (\%) } & \multirow{2}{*}{ Keterangan } \\
\hline & & Ya & Tidak & \\
\hline 1 & $\begin{array}{l}\text { Perkalian merupakan materi yang sulit untuk } \\
\text { saya fahami }\end{array}$ & 19 & 81 & Positif \\
\hline \multirow[t]{2}{*}{2} & $\begin{array}{l}\text { Perkalian yang membuat saya kesulitan adalah } \\
\text { a. Perkalian } 1 \text { sampai } 5\end{array}$ & 25 & 75 & Positif \\
\hline & b. Perkalian 6 sampai 10 & 25 & 75 & Positif \\
\hline \multirow[t]{2}{*}{3} & $\begin{array}{l}\text { Dengan menggunakan metode jarimatika } \\
\text { membuat saya lebih mudah } \\
\text { a. Memahami materi perkalian }\end{array}$ & 75 & 25 & Positif \\
\hline & b. Menentukan hasil perkalian 6 sampai 10 & 94 & 6 & $\begin{array}{l}\text { Sangat } \\
\text { Positif }\end{array}$ \\
\hline \multirow{3}{*}{4} & $\begin{array}{l}\text { Cara yang digunakan pada metode jarimatika } \\
\text { ini lebih } \\
\text { a. Menantang }\end{array}$ & 69 & 31 & $\begin{array}{l}\text { Kurang } \\
\text { Positif }\end{array}$ \\
\hline & b. Menarik dan mudah & 94 & 6 & $\begin{array}{l}\text { Sangat } \\
\text { Positif }\end{array}$ \\
\hline & c. Sulit untuk difahami & 19 & 81 & Positif \\
\hline \multirow[t]{2}{*}{5} & $\begin{array}{l}\text { Untuk menyelesaikan perkalian di atas } 5 \text {, saya } \\
\text { menggunakan } \\
\text { a. Metode menghafal }\end{array}$ & 44 & 56 & $\begin{array}{l}\text { Kurang } \\
\text { Positif }\end{array}$ \\
\hline & b. Metode jarimatika & 81 & 19 & Positif \\
\hline & & Senang & $\begin{array}{c}\text { Tidak } \\
\text { Senang }\end{array}$ & \\
\hline \multirow{2}{*}{6} & $\begin{array}{l}\text { Perasaan saya terhadap } \\
\text { a. Metode jarimatika }\end{array}$ & 94 & 6 & $\begin{array}{l}\text { Sangat } \\
\text { Positif }\end{array}$ \\
\hline & b. Suasana belajar di kelas & 100 & 0 & $\begin{array}{l}\text { Sangat } \\
\text { Positif }\end{array}$ \\
\hline
\end{tabular}

\section{Pembahasan}

Untuk mengetahui efektivitas pembelajaran ada empat aspek yang diteliti, antara lain ketuntasan belajar siswa, aktivitas siswa dan guru, kemampuan guru mengelola pembelajaran dan respon siswa.

Dalam penelitian ini, peneliti memberikan tes kepada 16 siswa dan hasil dari tes dihitung dengan bantuan Microsoft Excel 2007. Pada Tabel 1 dapat dilihat hasil perolehan skor tes yang diberikan kepada masing-masing siswa yang tuntas ada 12 siswa memperoleh skor di atas $60 \%$ atau di atas 60 dan ada 4 siswa yang tidak tuntas. Sedangkan secara klasikal dari 16 siswa yang mengikuti tes ada $75 \%$ yang tuntas.

Kemampuan guru dalam mengelola pembelajaran ditunjukkan pada Tabel 2 yang dihitung dengan mencari rata-rata dari ke lima pertemuan kemudian melihat hasil rata-rata pada kriteria kemampuan guru. Kriteria kemampuan guru diperoleh dari rumus sturges untuk memperoleh banyak kelas dan juga rentang 
penilaian. Dari ke lima pertemuan menunjukkan tingkat kemampuan guru berada pada kriteria baik. Dari hasil analisis tersebut dapat dilihat bahwa kemampuan guru dalam mengelola pembelajaran adalah efektif.

Aktivitas siswa dan guru diperoleh berdasarkan hasil pengamatan yang dicatat selama 5 menit sekali dalam tiap pertemuan. Adapun hasil aktivitas siswa ditunjukkan pada Tabel 3 yang menunjukkan setiap aktivitas siswa berada dalam rentang waktu ideal yang telah ditentukan. Dan pada Tabel 4 menunjukkan setiap aktivitas guru berada dalam rentang yang sudah ditentukan, Sehingga aktivitas tersebut adalah efektif.

Dari Tabel 5 dapat dilihat bahwa pada perolehan skor angket yang diberikan kepada masing-masing siswa, sebanyak 1 siswa atau 6\% dari jumlah siswa beranggapan negatif dengan penerapan metode jarimatika. Sedangkan 15 siswa atau 94\% dari jumlah siswa beranggapan positif dan sebanyak 16 siswa atau $100 \%$ dari jumlah siswa beranggapan positif terhadap suasana belajar di kelas. Hal ini menunjukkan bahwa siswa merasa kegiatan pembelajaran di kelas memotivasi siswa untuk mengikuti sampai kegiatan pembelajaran tersebut berakhir.

\section{SIMPULAN}

Simpulan berikut ini merupakan jawaban berdasarkan rumusan masalah yang ada. Simpulan yang diambil berlaku untuk subyek penelitian yaitu siswa kelas 2 MI Al-Mustofa Surabaya tahun pelajaran 2014/2015 pada materi perkalian.

Berdasarkan analisis data penelitian diperoleh simpulan sebagai berikut :

1. Siswa yang tuntas belajar sebanyak $75 \%$ adalah 12 siswa dan siswa yang belum tuntas belajar sebanyak 4 siswa.

2. Kemampuan guru dalam mengelola pembelajaran pada setiap pertemuan adalah baik.

3. Seluruh aktivitas yang dilakukan siswa dan guru berada dalam rentang waktu yang sudah ditentukan dan aktivitas yang paling banyak dilakukan oleh siswa adalah

a. Memperhatikan penjelasan guru/teman 
b. Mengerjakan/menyelesaikan masalah

c. Tanya jawab kepada guru/teman

Sedangkan aktivitas yang dilakukan siswa saat menggunakan/ mempraktekkan metode jarimatika adalah siswa mengoperasikan dengan cepat, sistematis dan benar dengan menghitung terlebih dahulu jari yang dilipat, kemudian mengalikan jari yang berdiri dan selanjutnya menjumlahkan nilai pada jari yang dilipat dengan nilai jari yang berdiri.

Aktivitas yang paling banyak dilakukan oleh guru adalah
a. Memberikan latihan
b. Menyampaikan bahan
c. Mengamati kegiatan siswa

4. Respon yang ditunjukkan oleh siswa adalah positif dan dapat dikatakan bahwa metode jarimatika membuat siswa lebih termotivasi dalam mengikuti kegiatan pembelajaran dan dapat mempermudah siswa dalam mengoperasikan perkalian.

Berdasarkan analisis data ketuntasan belajar siswa, kemampuan guru dalam mengelola pembelajaran, aktivitas siswa dan guru, dan respon siswa serta, maka dapat disimpulkan bahwa metode jarimatika efektif diterapkan dalam pembelajaran materi perkalian di kelas 2 .

\section{DAFTAR PUSTAKA}

Putra, Sitiatava Rizema. 2012. Berbagai Alat Bantu untuk Mempermudah Belajar Matematika. Jogjakarta: DIVA Press.

Slavin, Robert. E, 2006. Psikologi Pendidikan Teori \& Praktik. Jilid 2. Jakarta: PT Indeks.

Trianto. 2009. Mendesain Model Pembelajaran Inovatif-Progresif. Jakarta: Kencana Prenada Media Group. 